and a list of requirements was formulated which was laid before Drs. Kaye, Dye, and Davis of the National Physical Laboratory, who undertook to draw up specifications for the manufacture of standard forks, and Messrs. J. and W. Ragg of Sheffield have completed a set which will shortly be available. The chief features of the standard fork are (1) the place where it should be struck is marked, (2) overtones should be inaudible within ten seconds of the fork being struck, (3) the pitch audible through air and bone to be the same, and (4) the rate of decay shall be such that the half intensity period of the vibrating fork in air shall be between three and ten seconds. Recommendations on the use of forks are given, the classical qualitative tests of hearing are surveyed and their clinical significance stated, and quantitative tests are discussed. Several memoranda on various aspects of the subject are contained in an appendix. The report is one of considerable value and interest.

\section{American Association for the Advancement of Science}

ON December 30 the following officers of the American Association for the Advancement of Science were elected: President: Dr. Henry Norris Russell, Princeton University ; Permanent Secretary : Prof. Henry B. Ward, University of Illinois ; General Secretary: Prof. Burton E. Livingston, Johns Hopkins University ; Treasurer : Mr. John L. Wirt, Carnegie Institution of Washington. Vice-Presidents and Chairmen of Sections: A (Mathematics), Prof. C. N. Moore, University of Cincinnati ; B (Physics), Dr. C. J. Davisson, Bell Telephone Laboratories; C (Chemistry), Prof. Arthur B. Lamb, Harvard University; D (Astronomy), Dr. V. M. Slipher, Lowell Observatory; E (Geology), Prof. Rollin T. Chamberlin, University of Chicago; $\mathrm{F}$ (Zoological Sciences), Prof. A. S. Pearse, Duke University; G (Botanical Sciences), Prof. K. M. Wiegand, Cornell University; H (Anthropology), Prof. T. Wingate Todd, Western Reserve University ; I (Psychology), Prof. Walter R. Miles, Yale University ; K (Social and Economic Sciences), Dr. Wesley C. Mitchell, Columbia University ; L (Historical and Philological Sciences), Mr. Waldo G. Leland, American Council of Learned Societies; M (Engineering), Mr. C. F. Kettering, General Motors Corporation; N (Medical Sciences), Prof. Charles R. Stockard, Cornell University; O (Agriculture), Mr. A. R. Mann, Cornell University; Q (Education), Prof. Walter F. Dearborn, Harvard University.

\section{Announcements}

IT is announced that Sir Charles Reed Peers, president of the Society of Antiquaries, has been appointed a trustee of the British Museum in succession to the late Viscount Dillon, who died on December 18.

THE Council of the Institution of Naval Architects has awarded the premium for the year 1932 to Dr. G. Kempf, and Herr H. Lerbs, of the Hamburg
Experimental Tank, for their joint paper : "Cavitation Experiments on a Model Propeller".

AT the meeting of the London Mathematical Society on February 16 at 5 P.M. at Burlington House, Prof. P. A. M. Dirac will deliver a lecture on "The Relation between Classical and Quantum Mechanics". Members of other scientific societies are invited to attend the lecture.

A $\mathrm{T}$ the ordinary scientific meeting of the Chemical Society held on January 19 the President announced that Prof. S. Sugden had been appointed honorary secretary until the annual general meeting on Mareh 30 , and that the Council had nominated Prof. G. T. Morgan to the office of president and Prof. S. Sugden and Dr. J. M. Gulland as honorary secretaries to fill the vacant places that fall due to be filled at the annual general meeting.

The Council of the National Institute of Agricultural Botany has awarded the Snell memorial medal for 1932 to Dr. Kenneth M. Smith, entomologist of the Potato Virus Research Station, University of Cambridge. The medal is given to mark eminent work in the sphere of potato husbandry and it has been awarded to Dr. Smith in recognition of his valuable research work on the virus diseases of the potato. This has not only thrown much light on the methods of transmission of these diseases but has also had far-reaching influences on the whole plant virus problem.

As a result of further conferences between the "Dechema" (Deutsche Gesellschaft für chemisches Apparatewesen), the Verein deutscher Chemiker, the Verein deutscher Maschinenbauanstalten and the civic authorities of Cologne, it has been decided that, without interfering with the preparations in hand for the chemical plant exhibition "Achema VII", the date should be changed. The date for the exhibition, which will be held in Cologne, has therefore been finally fixed for May 18-27, 1934. The exhibition "Kautschuk" of the German Society for Rubber Industries which was to be held in conjunction with "Achema VII" will take place independently during 1933 in Cologne.

Applications are invited for the following appointments, on or before the dates mentioned :--Lecturers and instructors in various scientific subjects in evening institutes of the London County Council-The Education Officer, The County Hall, London, S.E.l (Feb. 10). An Esher research student to carry out research in the history or archæology of LondonThe Secretary, London Museum, Lancaster House, St. James's, London, S.W.I (March 11). A professor of agriculture at the University of Reading-The Registrar. An engineering workshop instructor and lecturer in workshop processes, drawing, calculations and science at the Borough Polytechnic, Borough Road, London, S.E.1-The Principal. 